\title{
Is There an Association between Advanced Stage of Renal Cell Carcinoma and Paraneoplastic Syndrome?
}

\author{
Guan-Xiong Ding $^{\mathrm{a}}$ Ning-Hong Song ${ }^{\mathrm{b}}$ Chen-Chen Feng ${ }^{\mathrm{a}}$ Guo-Wei Xia ${ }^{\mathrm{a}}$ \\ Hao-Wen Jiang ${ }^{a}$ Li-Xin Huab ${ }^{b}$ Qiang Ding ${ }^{a}$ \\ Department of Urology, ${ }^{a}$ Huashan Hospital, Fudan University, Shanghai, and ${ }^{b}$ First Affiliated Hospital, \\ Nanjing Medical University, Nanjing, PR China
}

\section{Key Words}

Paraneoplastic syndrome $\cdot$ Pyrexia $\cdot$ Renal cell carcinoma

\begin{abstract}
Objective: To investigate any association between renal cell carcinoma (RCC) and paraneoplastic syndromes (PNS). Subjects and Methods: The retrospective analysis included 1,028 patients of Chinese Han nationality with resectable RCC and PNS. The PNS included elevated erythrocyte sedimentation rate (ESR), hypertension, cachexia, anemia, pyrexia, abnormal liver function, hypercalcemia, polycythemia, varicocele and neuromyopathy. Staging was categorized as local (T1-2NOM0) and locally advanced (T3-4NxM0). Results: Among patients with at least one PNS, elevated ESR $(p=0.008)$, cachexia $(p=0.000)$, varicocele $(p=0.000)$ and pyrexia ( $p=0.021$ ) were related to advanced stage of RCC. Among patients with only one PNS, hypertension $(p=0.012)$ and hypercalcemia $(p=0.000)$ were related to advanced stage. The remaining PNS were not associated with tumor stage. Conclusion: Pyrexia, elevated ESR, cachexia and varicocele were related to advanced RCC. Hypertension and hypercalcemia occurring as single PNS, although also correlated with advanced stage, require further investigation.
\end{abstract}

Copyright $\odot 2012$ S. Karger AG, Basel

G.-X. Ding, N.-H. Song and C.-C. Feng contributed equally to this paper.

\section{Introduction}

Renal cell carcinoma (RCC) is derived from renal tubular epithelium. The incidence of RCC is generally higher in Europe and North America than Asia and South America; however, across continents, RCC incidence varies from country to country $[1,2]$. Other than the classic triads of hematuria, flank pain or flank mass, which occurs in less than $40 \%$ of patients on admission, RCC has a variety of other paraneoplastic syndromes (PNS), which may coexist with the classic triad of symptoms or alone. There is convincing evidence that RCC cells secrete proteins that serve as mediators of endocrine or nonendocrine PNS [3]. Therefore, the syndromes of RCC can be divided into two categories: endocrine and nonendocrine groups.

The endocrine group is less common and occurs in patients with hormonal manifestations secondary to neoplasm. The nonendocrine group consists of patients with a variety of systemic manifestations of the neoplastic disease. However, there is a dearth of studies pertaining to PNS and RCC stages $[3,4]$. Whether or not these manifestations have any relationship to the disease stage remains unclarified. Therefore, in the present study, we investigated the inherent relations between PNS and RCC stages within the Chinese Han population, a predominant ethnic group.

\section{KARGER}

Fax +41613061234

E-Mail karger@karger.ch

www.karger.com
(C) 2012 S. Karger AG, Basel

1011-7571/12/0214-0370\$38.00/0

Accessible online at:

www.karger.com/mpp 


\section{Subjects and Methods}

\section{Clinical Features}

A total of 1,512 patients who underwent radical nephrectomy or nephron-sparing surgery for pathologically confirmed unilateral RCC from the Huashan Hospital and the First Affiliated Hospital of Nanjing Medical University between 1994 and 2009 were included in the study. Each patient had a complete series of examinations including erythrocyte blood sedimentation rate (ESR), calcium levels, computed tomography (CT) or magnetic resonance imaging, chest X-ray or CT. Pathological profiles were classified according to the American Joint Committee on Cancer (AJCC, 2002) and Heidelberg guidelines. The diagnosis of PNS was determined on admission. Patients with preexisting diseases such as hypertension and iron deficiency anemia were excluded. All subjects were ethnic Han Chinese and permanent residents of the southern area of China. Ethical approval was obtained from the Institutional Review Boards of both hospitals and written informed consent was signed by all the patients.

\section{Operative Range and Staging}

Clinical staging was done by radiological evidence and corresponding auxiliary examinations based on the AJCC (2002). The operative strategy of RCC was based on a variety of predisposition factors that included tumor size, location, local and distant metastasis, preoperative renal function, and comorbidities. Resection of hilar lymph nodes was routinely performed to obtain adequate information for pathological staging. Enlarged lymph nodes that were detected by preoperative CT or intraoperatively were also dissected. Postoperative follow-up included chest and abdominal CT and blood tests which were standardized. The patients were followed up for 6 months to 2 years.

\section{Statistical Analysis}

Comparisons between the diverse PNS and clinicopathological features of RCC were evaluated using Fisher's exact or $\chi^{2}$ test. Statistical analyses were processed using SAS software package (SAS Institute Inc., Cary, N.C., USA); $p<0.05$ was considered statistically significant.

\section{Results}

\section{Patient Characteristics}

Among the 1,512 patients with RCC, 1,028 (67.98\%) subjects were diagnosed with paraneoplastic presentations based on elevated ESR, hypertension, cachexia, anemia, pyrexia, abnormal liver function, hypercalcemia, polycythemia, homonymy varicocele, and neuromyopathy. Cancer was detected on the left side in 557 cases and on the right in the remaining 471 (45.8\%) cases. Of the 1,028 subjects, $756(23.5 \%)$ were male and 272 (26.5\%) female with a mean age of $63 \pm 13.2$ years (range 28-81). The male:female ratio was 2.8:1 and left:right ratio was 1.2:1. The average size of the tumor was $6.2 \mathrm{~cm}$ (range 2.5-21). There were 657 (43.45\%) cases diagnosed incidentally, and

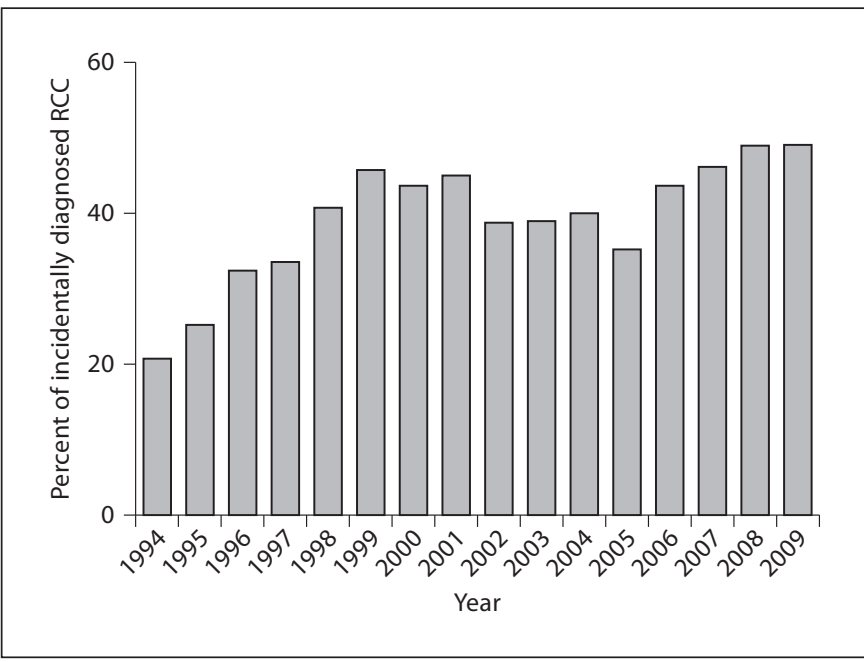

Fig. 1. Percentage of incidentally diagnosed RCC cases among 1,518 patients included from 1994 to 2009 .

in $89(13.55 \%)$ of these patients RCC was associated with PNS. The rate of incidentally diagnosed RCC seems to have an increasing trend over the years (fig. 1). A laparoscopic approach was performed in $412(40.0 \%)$ patients and open surgery was conducted in $616(60.0 \%)$ subjects. Nephron-sparing surgery was performed in 498 (48.4\%) patients whilst the rest underwent radical nephrectomy.

\section{Pathologic Features}

Pathologically confirmed tumors were T1a: 347 (33.7\%); T1b: 189 (18.4\%); T2: 414 (40.3\%); T3a: 28 (2.7\%); T3b: 19 (1.8\%); T3c: 9 (0.9\%); and T4: 22 (2.1\%). Twenty cases were positive for nodes (N1: 16 and N2: 4). Metastasis was not noticed in any case. There were 799 (77.7\%) patients diagnosed with clear-cell RCC, 187 (18.2\%) with papillary RCC, 36 (3.5\%) with chromophobic RCC, and 6 $(0.6 \%)$ patients with unspecified or mixed RCC. Staging was as follows: stages I + II (localized RCC) in 950 (92.4\%) cases and stages III + IV (locally advanced RCC, without M1) in $78(7.6 \%)$ cases.

\section{Paraneoplastic Syndromes}

PNS profiles are summarized in table 1. In contrast, only 154 patients manifested the classic triad of symptoms: any two symptoms were present in 186 cases and any one symptom was noted in 355 cases. There were 333 subjects presenting one or more of the PNS as the initial symptoms. Types of PNS in all the 1,028 cases were as follows: elevated ESR: 537 (52.2\%); hypertension: 379 (36.8\%); cachexia: 345 (33.6\%); anemia: 321 (31.2\%); py- 
Table 1. Distribution of PNS among RCC patients and correlation between PNS and RCC staging

\begin{tabular}{|c|c|c|c|c|}
\hline PNS & & $\begin{array}{l}\text { Localized } \\
(\mathrm{T} 1+\mathrm{T} 2, \mathrm{~N} 0 \mathrm{M} 0)\end{array}$ & $\begin{array}{l}\text { Locally advanced } \\
(\mathrm{T} 3+\mathrm{T} 4, \mathrm{NxM} 0)\end{array}$ & $\mathrm{p}$ value \\
\hline Elevated ESR & $\begin{array}{l}- \\
+\end{array}$ & $\begin{array}{l}465(94.70) \\
485(90.32)\end{array}$ & $\begin{array}{l}26(5.30) \\
52(9.68) \\
\end{array}$ & $0.008^{*}$ \\
\hline Hypertension & $\overline{+}$ & $\begin{array}{l}604(93.06) \\
346(91.29)\end{array}$ & $\begin{array}{l}45(6.94) \\
33(8.71)\end{array}$ & 0.300 \\
\hline Cachexia & $\begin{array}{l}- \\
+\end{array}$ & $\begin{array}{l}649(95.02) \\
301(87.25) \\
\end{array}$ & $\begin{array}{l}34(4.98) \\
44(12.75) \\
\end{array}$ & $0.000^{*}$ \\
\hline Anemia & $\overline{-}+$ & $\begin{array}{l}660(93.35) \\
290(90.34)\end{array}$ & $\begin{array}{l}47(6.65) \\
31(9.66)\end{array}$ & 0.091 \\
\hline Pyrexia & $\begin{array}{l}- \\
+\end{array}$ & $\begin{array}{l}731(93.48) \\
219(89.02) \\
\end{array}$ & $\begin{array}{l}51(6.52) \\
27(10.98)\end{array}$ & $0.021^{*}$ \\
\hline $\begin{array}{l}\text { Abnormal liver } \\
\text { function }\end{array}$ & $\begin{array}{l}- \\
+\end{array}$ & $\begin{array}{l}812(92.06) \\
138(94.52)\end{array}$ & $\begin{array}{r}70(7.94) \\
8(5.48)\end{array}$ & 0.299 \\
\hline Polycythemia & $\begin{array}{l}- \\
+\end{array}$ & $\begin{array}{r}892(92.34) \\
58(93.55) \\
\end{array}$ & $\begin{array}{r}74(7.66) \\
4(6.45) \\
\end{array}$ & 0.728 \\
\hline Varicocele $^{\mathrm{a}}$ & $\begin{array}{l}- \\
+\end{array}$ & $\begin{array}{c}697(92.20) \\
3(0.40)\end{array}$ & $\begin{array}{l}30(3.96) \\
26(3.44)\end{array}$ & $0.000^{*}$ \\
\hline Neuromyopathy & $\begin{array}{l}- \\
+\end{array}$ & $\begin{array}{c}941(91.53) \\
9(0.88)\end{array}$ & $\begin{array}{r}75(7.30) \\
3(0.29)\end{array}$ & 0.053 \\
\hline Hypercalcemia & $\overline{+}$ & $\begin{array}{c}890(86.58) \\
60(5.83)\end{array}$ & $\begin{array}{r}69(6.71) \\
9(0.88)\end{array}$ & 0.095 \\
\hline
\end{tabular}

Figures in parentheses are percentages. Statistical significance: ${ }^{*} \mathrm{p}<0.05$.

a Only male patients were included of whom 56 were in advanced stage.

rexia: 246 (23.9\%); abnormal liver function: 146 (14.2\%); hypercalcemia: 69 (6.7\%); polycythemia: 62 (6.0\%); homonymy varicocele: 29 (2.8\%); neuromyopathy: 12 (1.2\%). Among the 333 patients whose PNS were the initial symptoms, the following proportion was acquired: pyrexia in 175 cases $(52.6 \%)$, anemia in 146 cases $(43.8 \%)$, hypertension in 101 cases (30.3\%), homonymy varicocele in 12 cases (3.6\%), and neuromyopathy in 4 cases $(1.2 \%)$.

\section{Association between PNS and Clinicopathological \\ Parameters}

The association between PNS and clinicopathological parameters is listed in table 1 : elevated ESR $(p=0.008)$, cachexia $(\mathrm{p}=0.000)$, varicocele $(\mathrm{p}=0.000)$ and pyrexia $(\mathrm{p}=0.021)$ were found to be significantly related to increasing stage. The postoperative recovery rate for each PNS is summarized in table 2 . There were only 152 patients presenting one PNS throughout the course. The symptoms were elevated ESR: 37; hypertension: 59; anemia: 20; py-
Table 2. Recovery from or improvement of PNS in RCC patients after tumorectomy

\begin{tabular}{lcl}
\hline PNS & $\begin{array}{l}\text { Patients } \\
\text { recovering }\end{array}$ & $\begin{array}{l}\text { Mean time to } \\
\text { recovery/ } \\
\text { improvement }\end{array}$ \\
\hline Elevated ESR & $101 / 537(18.81)$ & 1.4 months \\
Hypertension & $213 / 379(56.20)$ & 1.0 months \\
Cachexia & $12 / 345(3.48)$ & 3.6 months \\
Anemia & $128 / 321(39.88)$ & 4.2 months \\
Pyrexia & $230 / 246(93.49)$ & 0.3 months \\
Abnormal liver function & $127 / 146(86.99)$ & 1.7 months \\
Polycythemia & $62 / 62(100.00)$ & 3.2 months \\
Varicocele & $2 / 29(6.90)$ & 6.0 months \\
Neuromyopathy & $12 / 12(100.00)$ & 4.5 months \\
Hypercalcemia & $23 / 69(33.33)$ & 2.8 months \\
\hline
\end{tabular}

Figures in parentheses are percentages.

a Only male patients included.

Table 3. Relations between single PNS and staging parameters

\begin{tabular}{|c|c|c|c|c|}
\hline PNS & & $\begin{array}{l}\text { Localized } \\
\text { (T1 + T2, N0M0) }\end{array}$ & $\begin{array}{l}\text { Locally advanced } \\
(\mathrm{T} 3+\mathrm{T} 4, \mathrm{NxM} 0)\end{array}$ & $\mathrm{p}$ value \\
\hline \multirow[t]{2}{*}{ Elevated ESR } & - & 109 & 6 & \multirow[t]{2}{*}{0.072} \\
\hline & + & 31 & 6 & \\
\hline \multirow[t]{2}{*}{ Hypertension } & - & 90 & 3 & \multirow[t]{2}{*}{$0.012^{*}$} \\
\hline & + & 50 & 9 & \\
\hline \multirow[t]{2}{*}{ Anemia } & - & 122 & 10 & \multirow[t]{2}{*}{0.660} \\
\hline & + & 18 & 2 & \\
\hline \multirow[t]{2}{*}{ Pyrexia } & - & 131 & 12 & \multirow[t]{2}{*}{1.000} \\
\hline & + & 9 & 0 & \\
\hline \multirow[t]{2}{*}{ Hypercalcemia } & - & 122 & 3 & \multirow[t]{2}{*}{$0.000^{*}$} \\
\hline & + & 18 & 9 & \\
\hline
\end{tabular}

Statistical significance: ${ }^{*} \mathrm{p}<0.05$.

rexia: 9; and hypercalcemia: 27 . The relationship between single PNS and staging parameters is summarized in table 3. Hypertension and hypercalcemia occurring as single PNS were found to be associated with advanced stage.

\section{Discussion}

In this study, the $67.98 \%$ of patients with RCC and PNS are higher than the $10-40 \%$ reported previously $[3,4]$. The high occurrence of PNS in China could be due to tomography and a definition of PNS which could differ 
from center to center especially in case of hypertension, anemia or pyrexia.

Elevated ESR is one of the most common paraneoplastic manifestations of RCC. Our finding of $52 \%$ of patients with elevated ESR is within the range of $23-55 \%$ reported previously [5]. Furthermore, the results of the current study demonstrated that an elevated ESR was more common among patients with advanced stage. The mechanism of ESR elevation in RCC is poorly understood. Some researchers suggest a possible correlation with low hematocrit [5]. However, $20 \%$ of the patients in our cohort who had a normal or elevated hematocrit still had an elevated ESR, suggesting that this may not be the only factor involved. Although cachexia is a common sequela of advanced and metastatic RCC, it may also be a paraneoplastic finding. Anorexia, emaciation, inertia, malaise and weight loss were manifestations of cachexia. It has been suggested that the tumor may secrete substances responsible for paraneoplastic cachexia, which is related to a worsening prognosis in RCC [6] as cachexia was prevalent within patients with advanced tumor stage in our study.

In the present study, 29 males were diagnosed with varicocele. In fact, varicose gonadal veins are usually detected intraoperatively in female patients. Because there is a dearth of criteria defining the extent of these intraoperative findings, we were reluctant to include female patients for evaluation. Twelve patients showed a unilateral hypochondriac mass on physical examination whilst the rest were detected with ultrasonography. Nonetheless it remains controversial whether or not varicocele, merely a mechanical compression, can strictly be defined as a PNS. The inclusion of varicocele in this study was based on its relation to advanced-stage RCC. RCC tends to invade the renal veins and in more extensive cases a tumor thrombus may extend into the vena cava causing varicocele [7]. Malignancies are known to be a common source of pyrexia of unknown origin [8] as $24 \%$ of patients with RCC present pyrexia of unknown origin in our study. Of note, a significant correlation between pyrexia and advanced stage was obtained. Because necrosis and hemorrhage of the tumor have been thought to cause an elevated temperature [9], more prominent pyrexia may be caused by increased absorption of necrotic substance.

As many as a quarter of the patients were anemic, who did not appear to be secondary to blood loss and therefore could be regarded as normochromic and normocytic. Although malignancy-associated anemia has not been well characterized, it is thought to be secondary to marrow depression [10]. Although there was no relationship be-

Paraneoplastic Syndrome and Renal Cell Carcinoma Stage tween preoperative anemia and stage, the hematocrit of the patients returned to normal after resection of the primary tumors. Strictly defined PNS hypertension was present in up to $40 \%$ of patients in our series. Such PNS could be induced through a variety of mechanisms including hyperreninemia, polycythemia, hypercalcemia, renal arteriovenous fistula, and ureteral obstruction [11]. Though no significance was reached in linking hypertension to stage, postoperative blood pressure normalized in our subjects and there was no evidence of recurrence. Abnormal liver function associated with RCC has been explained in a variety of ways that include impairment of hepatic function by the inflammatory cytokine of interleukin-6, the secretion of hepatotoxins or lysosomal enzymes that stimulate hepatic cathepsins or phosphatases, by the tumor itself $[12,13]$. It has been postulated that tumor-secreted hepatotoxins cause hepatocyte injury with activation of the immune system which is mediated by the local recruitment of $\mathrm{T}$ cells and the production of antibodies against liver antigens [14]. However, the fact that $87 \%$ of patients with abnormal liver function reverted to normal function after tumorectomy showed that hepatic dysfunction associated with RCC is not necessarily a contraindication for surgery. As the kidney is involved in calcium metabolism and the maintenance of a normal hematocrit, hypercalcemia is well recognized to occur with RCC. However, the definition of nonmetastatic hypercalcemia is limited to the elevation of serum calcium levels in the presence of a tumor that has not spread to the bone. One possible mechanism for this symptom is the secretion of hormonal peptides by renal tumor cells [15]. Polycythemia, on the other hand, was associated with approximately $7 \%$ of patients in our study. The index decreased postoperatively within $2-3$ weeks in all patients. In these patients, elevated red blood cell concentration is believed to be mediated by erythropoietin, a glycoprotein that induces differentiation of erythrocyte colony-forming units in the bone marrow to promote red blood cell production. Neurological PNS are rare in RCC conditions yet can be successfully treated by resection of the primary tumor $[16,17]$. In our cohort, the 12 cases who were found to have neuromyopathy associated with RCC all experienced more or less alleviation of their condition postoperatively. Though hypertension and hypercalcemia were found to be associated with advanced stage as single PNS, it is still hard to evaluate their clinical significance since the number of these patients in our study is limited. Further investigations are required to clarify whether a single PNS virtually relates to clinicopathological features. 


\section{Conclusion}

The results indicated that pyrexia, elevated ESR, cachexia and varicocele were significantly more prevalent among patients with advanced-stage RCC in the Han ethnic group in China.

\section{Acknowledgments}

We thank Drs. Hong-Fei Wu, Zu-Jun Fang, and Xiang Wang for supportive scientific discussions. The authors have nothing else to disclose.

\section{References}

1 Chow WH, Dong LM, Devesa SS: Epidemiology and risk factors for renal cell carcinoma. Nat Rev Urol 2010;7:245-257.

$2 \mathrm{Ku} \mathrm{JH}$, Moon KC, Kwak C, Kim HH: Disease-specific survival in patients with renal cell carcinoma: an audit of a large series from Korea. Jpn J Clin Oncol 2011;41:110-114.

- 3 Kim HL, Belldegrun AS, Freitas DG, Bui MH, Han KR, Dorey FJ, Figlin RA: Paraneoplastic signs and symptoms of renal cell carcinoma: implications for prognosis. J Urol 2003;170:1742-1746.

4 Palapattu GS, Kristo B, Rajfer J: Paraneoplastic syndromes in urologic malignancy: the many faces of renal cell carcinoma. Rev Urol 2002;4:163-170.

5 Sengupta S, Lohse CM, Cheville JC: The preoperative erythrocyte sedimentation rate is an independent prognostic factor in renal cell carcinoma. Cancer 2006;106:304-312.

-6 Kim HL, Han KR, Zisman A, Figlin RA, Belldegrun AS: Cachexia-like symptoms predict a worse prognosis in localized t1 renal cell carcinoma. J Urol 2004;171:1810-1813.
Sacco E, Pinto F, Sasso F, Racioppi M, Gulino G, Volpe A, Bassi P: Paraneoplastic syndromes in patients with urological malignancies. Urol Int 2009;83:1-11.

8 Lin JN, Lai CH, Lu LF, Lin HH: Fever of unknown origin from a left atrial myxoma: an immunologic basis and cytokine association. South Med J 2011;104:360-362.

-9 Weiss RH, Lin PY: Renal cell carcinoma: identification of novel targets for therapy. Kidney Int 2006;69:224-232.

10 Handler J: Renal cell carcinoma and hypertension. J Clin Hypertens (Greenwich) 2005; 7:249-251.

11 Fryzek JP, Poulsen AH, Johnsen SP, McLaughlin JK, Sørensen HT, Friis S: A cohort study of antihypertensive treatments and risk of renal cell cancer. Br J Cancer 2005;92:1302-1306.

12 Altundag O, Altundag K, Gunduz E: Interleukin- 6 and C-reactive protein in metastatic renal cell carcinoma. J Clin Oncol 2005; 23:1044.

13 Giannakos G, Papanicolaou X, Trafalis D, Michaelidis I, Margaritis G, Christofilakis C: Stauffer's syndrome variant associated with renal cell carcinoma. Int J Urol 2005;12:757759 .
14 Miwa S, Mizokami A, Konaka H, Izumi K, Nohara T, Namiki M: A case of bone, lung, pleural and liver metastases from renal cell carcinoma which responded remarkably well to zoledronic acid monotherapy. Jpn J Clin Oncol 2009;39:745-750.

15 Ueno M, Tokonabe S, Kuroda I, Tsukamoto T, Deguchi N: Hypercalcemia upon recurrence of renal cell carcinoma producing parathyroid hormone-related protein. Scand J Urol Nephrol 2003;37:265-268.

16 Turka HM, Ozetb A, Kuzhanb O, Komurcuc F, Arpacib F, Ozturkb B, Ataerginb S: Paraneoplastic motor neuron disease resembling amyotrophic lateral sclerosis in a patient with renal cell carcinoma. Med Princ Pract 2009;18:73-75.

17 Chang M, Chen Y, Chen Y, Tian Y, Fang J, Yang C: Concurrent renal cell carcinoma and central nervous system lymphoma in a patient with autosomal dominant polycystic kidney disease. Med Princ Pract 2009;18: 486-489. 